\title{
Should we clone human beings? Cloning as a source of tissue for transplantation
}

\author{
Julian Savulescu The Murdoch Institute, Royal Children's Hospital, Melbourne, Australia
}

\begin{abstract}
The most publicly justifiable application of human cloning, if there is one at all, is to provide self-compatible cells or tissues for medical use, especially transplantation. Some have argued that this raises no new ethical issues above those raised by any form of embryo ${ }^{I}$ experimentation. I argue that this research is less morally problematic than other embryo research. Indeed, it is not merely morally permissible but morally required that we employ cloning to produce embryos or fetuses for the sake of providing cells, tissues or even organs for therapy, followed by abortion of the embryo or fetus.
\end{abstract}

(Fournal of Medical Ethics 1999;25:87-95)

Keywords: Cloning; transplantation; autonomy; embryonic stem cells; fetal tissue; embryo experimentation; abortion; potential

\section{Introduction}

When news broke in 1997 that Ian Wilmut and his colleagues had successfully cloned an adult sheep, there was an ill-informed wave of public, professional and bureaucratic fear and rejection of the new technique. Almost universally, human cloning was condemned. ${ }^{2-6}$ Germany, Denmark and Spain have legislation banning cloning; Norway, Slovakia, Sweden and Switzerland have legislation implicitly banning cloning. ${ }^{7}$ Some states in Australia, such as Victoria, ban cloning. There are two bills before congress in the US which would comprehensively ban it. ${ }^{89}$ There is no explicit or implicit ban on cloning in England, Greece, Ireland or the Netherlands, though in England the Human Embryology and Fertilisation Authority, which issues licences for the use of embryos, has indicated that it would not issue any licence for research into "reproductive cloning". This is understood to be cloning to produce a fetus or live birth. Research into cloning in the first 14 days of life might be possible in England. ${ }^{7}$

There have been several arguments given against human reproductive cloning:

1. It is liable to abuse.

2. It violates a person's right to individuality, autonomy, selfhood, etc.
3. It violates a person's right to genetic individuality (whatever that is-identical twins cannot have such a right).

4. It allows eugenic selection.

5. It uses people as a means.

6. Clones are worse off in terms of wellbeing, especially psychological wellbeing.

7. There are safety concerns, especially an increased risk of serious genetic malformation, cancer or shortened lifespan.

There are, however, a number of arguments in favour of human reproductive cloning. These include:

1. General liberty justifications.

2. Freedom to make personal reproductive choices.

3. Freedom of scientific enquiry.

4. Achieving a sense of immortality.

5. Eugenic selection (with or without gene therapy/enhancement).

6. Social utility - cloning socially important people.

7. Treatment of infertility (with or without gene therapy/enhancement).

8. Replacement of a loved dead relative (with or without gene therapy/enhancement).

9. "Insurance" - freeze a split embryo in case something happens to the first: as a source of tissue or as replacement for the first.

10. Source of human cells or tissue.

11. Research into stem cell differentiation to provide an understanding of aging and oncogenesis.

12. Cloning to prevent a genetic disease.

The arguments against cloning have been critically examined elsewhere and I will not repeat them here. ${ }^{1011}$ Few people have given arguments in favour of it. Exceptions include arguments in favour of $7-12,{ }^{12}$ with some commentators favouring only $10-11^{1314}$ or $11-12 .{ }^{15}$ Justifications 10-12 (and possibly 7) all regard cloning as a way of treating or avoiding disease. These have emerged as arguably the strongest justifications 
for cloning. This paper examines 10 and to some extent 11 .

\section{Human cloning as a source of cells or tissue}

Cloning is the production of an identical or nearidentical genetic copy. ${ }^{16}$ Cloning can occur by fission or fusion. Fission is the division of a cell mass into two equal and identical parts, and the development of each into a separate but genetically identical or near-identical individual. This occurs in nature as identical twins.

Cloning by fusion involves taking the nucleus from one cell and transferring it to an egg which has had its nucleus removed. Placing the nucleus in the egg reprogrammes the DNA in the nucleus to replicate the whole individual from which the nucleus was derived: nuclear transfer. It differs from fission in that the offspring has only one genetic parent, whose genome is nearly identical to that of the offspring. In fission, the offspring, like the offspring of normal sexual reproduction, inherits half of its genetic material from each of two parents. Henceforth, by "cloning", I mean cloning by fusion.

Human cloning could be used in several ways to produce cells, tissues or organs for the treatment of human disease.

\section{HUMAN CLONING AS A SOURCE OF MULTIPOTENT} STEM CELLS

In this paper I will differentiate between totipotent and multipotent stem cells. Stem cells are cells which are early in developmental lineage and have the ability to differentiate into several different mature cell types. Totipotent stem cells are very immature stem cells with the potential to develop into any of the mature cell types in the adult (liver, lung, skin, blood, etc). Multipotential stem cells are more mature stem cells with the potential to develop into different mature forms of a particular cell lineage, for example, bone marrow stem cells can form either white or red blood cells, but they cannot form liver cells.

Multipotential stem cells can be used as

a. a vector for gene therapy.

b. cells for transplantation, especially in bone marrow.

Attempts have been made to use embryonic stem cells from other animals as vectors for gene therapy and as universal transplantation cells in humans. Problems include limited differentiation. and rejection. Somatic cells are differentiated cells of the body, and not sex cells which give rise to sperm and eggs. Cloning of somatic cells from a person who is intended as the recipient of cell therapy would provide a source of multipotential stem cells that are not rejected. These could also ${ }^{\text {? }}$. be vectors for gene therapy. A gene could be inserted into a somatic cell from the patient $\frac{}{0}$ followed by selection, nuclear transfer and the culture of the appropriate clonal population of cells in vitro. These cells could then be returned too the patient as a source of new tissue (for exampleon bone marrow in the case of leukaemia) or as tissue without genetic abnormality (in the case of inherited genetic disease). The major experimenta $\vec{\omega}$ issues which would need to be addressed areo developing clonal stability during cell amplifica-3 tion and ensuring differentiation into the cell typef needed. ${ }^{13}$ It should be noted that this procedure does not necessarily involve the production of aoo multicellular embryo, nor its implantation in vivo or artificially. (Indeed, cross-species cloning fusing human cells with cow eggs-produces embryos which will not develop into fetuses, let? alone viable offspring. ${ }^{17}$ )

A related procedure would produce totipotente stem cells which could differentiate into multipo-tent cells of a particular line or function, or eveno into a specific tissue. This is much closer to reproductive cloning. Embryonic stem cells from mice have been directed to differentiate into vascularo endothelium, myocardial and skeletal tissue, haemopoietic precursors and neurons. ${ }^{18}$ However, itô is not known whether the differentiation of human totipotent stem cells can be controlled in vitro Unlike the previous application, the production of organs could involve reproductive cloning (the production of a totipotent cell which forms a blas $-\dot{-}$ tomere), but then differentiates into a tissue after some days. Initially, however, all early embryonico cells are identical. Producing totipotent stem cells in this way is equivalent to the creation of an earlys embryo.

PRODUCTION OF EMBRYO/FETUS/CHILD/ADULT AS A N SOURCE OF TISSUE

An embryo, fetus, child or adult could be produced by cloning, and solid organs orw differentiated tissue could be extracted from it. 设

\section{Cloning as source of organs, tissue and cells for transplantation} THE NEED FOR MORE ORGANS AND TISSUES
Jeffrey Platts reports: "So great is the demand that as few as $5 \%$ of the organs needed in the Unitedळ States ever become available". ${ }^{19}$ According too David K C Cooper, this is getting worse: "The discrepancy between the number of potentia) recipients and donor organs is increasing by approximately $10-15 \%$ annually". ${ }^{20}$ Increasing 
procurement of cadaveric organs may not be the solution. Anthony Dorling and colleagues write:

"A study from Seattle, USA, in 1992 identified an annual maximum of only 7,000 brain dead donors in the USA. Assuming $100 \%$ consent and suitability, these 14,000 potential kidney grafts would still not match the numbers of new patients commencing dialysis each year. The clear implication is that an alternative source of organs is needed." 21

Not only is there a shortage of tissue or organs for those with organ failure, but there remain serious problems with the compatibility of tissue or organs used, requiring immunosuppressive therapy with serious side effects. Using cloned tissue would have enormous theoretical advantages, as it could be abundant and there is near perfect immunocompatibility. $^{22}$

There are several ways human cloning could be used to address the shortfall of organs and tissues, and each raises different ethical concerns.

\section{PRODUCTION OF TISSUE OR CELLS ONLY BY CONTROLLING DIFFERENTIATION}

I will now give an argument to support the use of cloning to produce cells or tissues through control of cellular differentiation.

\section{The fate of one's own tissue}

Individuals have a strong interest or right in determining the fate of their own body parts, including their own cells and tissues, at least when this affects the length and quality of their own life. A right might be defended in terms of autonomy or property rights in body parts.

This right extends (under some circumstances) both to the proliferation of cells and to their transmutation into other cell types (which I will call the Principle of Tissue Transmutation).

\section{Defending the Principle of Tissue Transmutation Consider the following hypothetical example:}

Lucas I Lucas is a 22-year-old man with leukaemia. The only effective treatment will be a bone marrow transplant. There is no compatible donor. However, there is a drug which selects a healthy bone marrow cell and causes it to multiply. A doctor would be negligent if he or she did not employ such a drug for the treatment of Lucas's leukaemia. Indeed, there is a moral imperative to develop such drugs if we can and use them. Colony-stimulating factors, which cause blood cells to multiply, are already used in the treatment of leukaemia, and with stored marrow from those in remission in leukaemia before use for reconstitution during relapse.

Lucas II In this version of the example, the drug causes Lucas's healthy skin cells to turn into healthy bone marrow stem cells. There is no relevant moral difference between Lucas I and II. We should develop such drugs and doctors would be negligent if they did not use them.

If this is right, there is nothing problematic about cloning to produce cells or tissues for transplantation by controlling differentiation. All we would be doing is taking, say, a skin cell and turning on and off some components of the total genetic complement to cause the cell to divide as a bone marrow cell. We are causing a differentiated cell (skin cell) to turn directly into a multipotent stem cell (bone marrow stem cell).

Are there any objections? The major objection is one of practicality. It is going to be very difficult to cause a skin cell to turn directly into a bone marrow cell. There are also safety considerations. Because we are taking a cell which has already undergone many cell divisions during terminal differentiation to give a mature cell such as a skin cell, and accumulated mutations, there is a theoretical concern about an increased likelihood of malignancy in that clonal population. However, the donor cell in these cases is the same age as the recipient (exactly), and a shorter life span would not be expected. There may also be an advantage in some diseases, such as leukemia, to having a degree of incompatibility between donor and recipient bone marrow so as to enable the donor cells to recognise and destroy malignant recipient cells. This would not apply to non-malignant diseases in which bone marrow transplant is employed, such as the leukodystrophies. Most importantly, all these concerns need to be addressed by further research.

Lucas IIA In practice, it is most likely that skin cells will not be able to be turned directly into bone marrow cells: there will need to be a stage of totipotency in between. The most likely way of producing cells to treat Lucas II is via the cloning route, where a skin cell nucleus is passed through an oocyte to give a totipotent cell. The production of a totipotent stem cell is the production of an embryo.

Production of an embryo as a source of cells or tissues There are two ways in which an embryo could be a source of cells and tissues. Firstly, the early embryonic cells could be made to differentiate into cells of one tissue type, for example, bone 
marrow. Secondly, differentiated cells or tissues from an older embryo could be extracted and used directly.

Are these permissible?

In England, the Royal Society ${ }^{15}$ has given limited support to cloning for the purposes of treating human disease. The Human Genetics Advisory Commission (HGAC) defines this as "therapeutic cloning," differentiating it from "reproductive cloning", " Both bodies claim that embryo experimentation in the first 14 days is permitted by English law, and question whether cloning in this period would raise any new ethical issues.

Cloning in this circumstance raises few ethical issues. What is produced, at least in the first few days of division after a totipotent cell has been produced from an adult skin cell, is just a skin cell from that person with an altered gene expression profile (some genes turned on and some turned off). In one way, it is just an existing skin cell behaving differently from normal skin cells, perhaps more like a malignant skin cell. The significant processes are ones of cellular multiplication and later, cellular differentiation.

If this is true, why stop at research at 14 days? Consider the third version of the Lucas case:

Lucas III The same as Lucas IIA, but in this case, Lucas also needs a kidney transplant. Therefore, in addition to the skin cell developing blood stem cells (via the embryo), the process is adjusted so that a kidney is produced.

The production of another tissue type or organ does not raise any new relevant ethical consideration. Indeed, if Lucas did not need the kidney, it could be used for someone else who required a kidney (if, of course, in vitro maturation techniques had been developed to the extent that a functioning organ of sufficient size could be produced).

\section{Consider now:}

Lucas IV In addition to the blood cells, all the tissue of a normal human embryo is produced, organised in the anatomical arrangement of an embryo. This (in principle) might or might not involve development in a womb. For simplicity, let us assume that this occurs in vitro (though this is impossible at present).

Is there any morally relevant difference from the previous versions? It is not relevant that many different tissues are produced rather than one. Nor is the size of these tissues or their arrangement morally relevant. If there is a difference, it must be that a special kind of tissue has been produced, or that some special relationship develops between exist $\overrightarrow{\bar{z}}$ ing tissues, and that a morally significant entity? then exists. When does this special point int embryonic development occur?

The most plausible point is some point during the development of the brain. There are two mair candidates:

1. when tissue differentiates and the first identifits able brain structures come into existence as the neural plate around day $19 .^{23}$

2. when the brain supports some morally sig nificant function: consciousness or self consciousness or rational self-consciousness The earliest of these, consciousness, does not occur until well into fetal development.

On the first view, utilisation of cloning techniqueg in the first two weeks to study cellular differentia tion is justifiable. The most defensible view, $\mathbb{Z}$ believe, is that our continued existence only. becomes morally relevant when we become self $\vec{\imath}$ conscious. (Of course, if a fetus can feel pain a some earlier point, but is not self-conscious, it existence is morally relevant in a different way: we ought not to inflict unnecessary pain on it, though it may be permissible to end its life painlessly.) Orof this view, we should use the drug to cause Lucas IV's skin cells to transmutate and remove bone marrow from these. What is going on in Lucas IV is no different, morally speaking, from cloning. If this is right, it is justifiable to extract differentiate tissues from young fetuses which have been cloned

\section{Conception and potentiality}

The other usual point in development which is taken to be morally significant is conception. ${ }^{2} \frac{\delta}{2}$ However, in the case of cloning, there is nQ conception. There is just a process of turning. some switches in an already existing cell. Proporn nents of the persons-begin-to-exist-at-conception view might reply that cloning is like conception An individual begins to exist at the point of nuclear transfer. But why should we accept this Conception seems quite different. Conceptio involves the unification of two different entitiesक the sperm and the egg, to form a new entity, the totipotent stem cell. In the case of cloning, there ist identity between the cell before and after nuclea transfer-it is the same cell. Something new and important does happen to the entity when iq undergoes nuclear transfer, just as something new and important happens when a cell with a maligo nant potential becomes malignant. But it is the same cell. 


\section{POTENTIALITY}

In response, one might claim that after nuclear transfer the cell undergoes a radically and morally significant change: it acquires the potential to be a person. On this view, the cell immediately prior to nuclear transfer does not have the potential to be a human being but after nuclear transfer, it has the potential to be a human being. This has a jarring ring to it. What happens when a skin cell turns into a totipotent stem cell is that a few of its genetic switches are turned on and others turned off. To say it doesn't have the potential to be a human being until its nucleus is placed in the egg cytoplasm is like saying my car does not have the potential to get me from Melbourne to Sydney unless the key is turned in the ignition. (Rather, we should say that it has the potential but that that potential may not be realised if the key is not turned in the ignition.) Or it is like saying that a stick of dynamite acquires the potential to cause an explosion when placed in the vicinity of a lighted match. Of course, a stick of dynamite has the potential to cause an explosion, and various conditions, including placing it in the vicinity of a lighted match, are sufficient to realise this potential. In general terms, $\mathrm{X}$ has the potential to be $\mathrm{Y}$, if $\mathrm{X}$ would be a $\mathrm{Y}$ if conditions $\mathrm{c}, \mathrm{d}, \mathrm{e}, \ldots$ obtained. Nuclear transfer is like a number of other conditions (such as adequate placental blood flow) which must obtain if a skin cell is to become a person.

There may be another difference between a mature skin cell and a fertilised egg. Totipotent cells directly give rise to human beings but mature skin cells do not. The latter must go through a further stage of totipotency first. And it may be that that change is significant enough to say that the skin cell does not itself have the potential to create a human being. However, something with the potential to cause A may not lead directly to A. Killing the president may not lead directly to a world war. However, it may lead to political destabilisation which will cause a world war. Killing the president does then have the potential to cause a world war.

At bottom, these issues may be semantic, and depend on how we choose to define "potential." What matters morally is whether skin cells can become human beings with the application of technology, and whether they should. That is an important moral feature of nuclear transfer. Nuclear transfer is a technical intervention which it is necessary to employ if a skin cell is to become a person, just as microsurgical transfer of an embryo formed in vitro is necessary if the embryo is to become a person.

I cannot see any intrinsic morally significant difference between a mature skin cell, the totipotent stem cell derived from it, and a fertilised egg.
They are all cells which could give rise to a person if certain conditions obtained. (Thus, to claim that experimentation on cloned embryos is acceptable, but the same experimentation on non-cloned embryos is not acceptable, because the former are not embryos but totipotent stem cells, is sophistry.)

Looking at cloning this way exposes new difficulties for those who appeal to the potential of embryos to become persons and the moral significance of conception as a basis for opposition to abortion. If all our cells could be persons, then we cannot appeal to the fact that an embryo could be a person to justify the special treatment we give it. Cloning forces us to abandon the old arguments supporting special treatment of fertilised eggs.

\section{PRODUCTION OF A FETUS}

If one believes that the morally significant event in development is something related to consciousness, then extracting tissue or organs from a cloned fetus up until that point at which the morally relevant event occurs is acceptable. Indeed, in law, a legal persona does not come into existence until birth. At least in Australia and England, abortion is permissible throughout fetal development.

PRODUCTION OF A CHILD OR ADULT AS A SOURCE OF CELLS OR TISSUES

Like the production of a self-conscious fetus, the production of a cloned child or adult is liable to all the usual cloning objections, together with the severe limitations on the ways in which tissue can be taken from donors for transplantation.

Many writers support cloning for the purposes of studying cellular differentiation because they argue that cloning does not raise serious new issues above those raised by embryo experimentation. ${ }^{15}$ Such support for cloning is too limited. On one view, there is no relevant difference between early embryo research and later embryo/early fetal research. Indeed, the latter stand more chance of providing viable tissue for transplantation, at least in the near future. While producing a cloned live child as a source of tissue for transplantation would raise new and important issues, producing embryos and early fetuses as a source of tissue for transplantation may be morally obligatory.

\section{Consistency}

Is this a significant deviation from existing practice?

\section{FETAL TISSUE TRANSPLANTATION}

In fact, fetal tissue has been widely used in medicine. Human fetal thymus transplantation is standard therapy for thymic aplasia or Di George's 
syndrome. It has also been used in conjunction with fetal liver for the treatment of subacute combined immunodeficiency.

Human fetal liver and umbilical cord blood have been used as a source of haematopoietic cells in the treatment of acute leukaemia and aplastic anaemia. Liver has also been used for radiation accidents and storage disorders. The main problem has been immune rejection. ${ }^{25}$

One woman with aplastic anaemia received fetal liver from her own 22-week fetus subsequent to elective abortion over 20 years ago. ${ }^{26}$

Fetal brain tissue from aborted fetuses has been used as source of tissue for the treatment of Parkinson's disease. Neural grafts show long term survival and function in patients with Parkinson's disease, though significant problems remain. ${ }^{27} 28$

Fetal tissue holds promise as treatment for Huntington's disease, ${ }^{2930}$ spinal cord injuries, ${ }^{31}$ demyelinating disorders, ${ }^{27}$ retinal degeneration in retinitis pigmentosa, ${ }^{32} 33$ hippocampal lesions associated with temporal lobe epilepsy, cerebral ischaemia, stroke and head injury, ${ }^{34}$ and beta thalassemia in utero using fetal liver. ${ }^{35}$ Fetal pancreas has also been used in the treatment of diabetes.

\section{Fetal tissue banks}

Indeed, in the US and England, fetal tissue banks exist to distribute fetal tissues from abortion clinics for the purposes of medical research and treatment. In the US, the Central Laboratory for Human Embryology in Washington, the National Diseases Research Interchange, and the International Institute for the Advancement of Medicine and the National Abortion Federation, all distribute fetal tissue.

In the UK, the Medical Research Council's fetal tissue bank was established in 1957 and disperses about 5,000 tissues a year.

\section{CONCEPTION OF A NON-CLONED CHILD AS A} SOURCE OF BONE MARROW: AYALA CASE

Not only has fetal tissue been used for the treatment of human disease, but human individuals have been deliberately conceived as a source of tissue for transplantation. In the widely discussed Ayala case, a 17-year-old girl, Anissa, had leukaemia. No donor had been found in two years. Her father had his vasectomy reversed with the intention of having another child to serve as a bone marrow donor. There was a one in four chance the child would be compatible with Anissa. The child, Marissa, was born and was a compatible donor and a successful transplant was performed. ${ }^{36}$

A report four years later noted: "Marissa is now a healthy four-year-old, and, by all accounts, as loved and cherished a child as her parents said she would be. The marrow transplant was a success, and Anissa is now a married, leukaemia-free, bank Assisted reproduction (IVF) has been used to produce children to serve as bone marrow donors. ${ }^{38}$ It is worth noting that had cloning been available, there would have been a $100 \%$ chance ofen perfect tissue compatibility and a live child needळ not have been produced.

\section{Objections}

While there are some precedents for the proposal to use cloning to produce tissue for transplantation what is distinctive about this proposal is that human tissue will be: (i) cloned and (ii) deliberately createdor with abortion in mind. This raises new objections

ABORTION IS WRONG

Burtchaell, a Catholic theologian, in considering the ethics of fetal tissue research, claims tha? abortion is morally wrong and that fetal tissue cannot be used for research because no one cane give informed consent for its use and to use it would be complicity in wrongful killing. ${ }^{39} \mathrm{HeO}$ claims that mothers cannot consent: "The flaw ins this claim [that mothers can consent] is that the tissue is from within her body but is the body of another, with distinct genotype, blood, gender? etc." Claims such as those of Burtchaell are moreo problematic in the case of cloning. If the embryo 3 were cloned from the mother, it would be of the same genotype as her, and, arguably, one of her. tissues. Now at some point a cloned tissue is no longer just a tissue from its clone: it exists as an individual in its own right and at some point has interests as other individuals do. But the latte point occurs, I believe, when the cloned individuaß becomes self-conscious. The presence or absenceg of a distinct genotype is irrelevant. We are not jus $\rightarrow$ tified in treating an identical twin differently from a non-identical twin because the latter has an distinct genotype.

In a society that permits abortion on demand sometimes for little or no reason, it is hard to seew how women can justifiably be prevented fron aborting a fetus for the purpose of savinge someone's life. And surely it is more respectful o the fetus, if the fetus is an object of respect, that its body parts be used for good rather than for no good purpose at all.

\section{IT IS WORSE TO BE A CLONE}

Some have argued that it is worse to be a clone. This may be plausible in the sense that a persong suffers in virtue of being a clone - living in the shadow of its "parent", feeling less like ate 
individual, treated as a means and not an end, etc. Thus cloning in the Ayala case would raise some new (but I do not believe overwhelming) issues which need consideration. But cloning followed by abortion does not. I can't make any sense of the claim that it is worse to be a cloned cell or tissue. These are not the things we ascribe these kinds of interests to. Cloning is bad when it is bad for a person. Likewise, arguments regarding "instrumentalisation" apply to persons, and not to tissues and cells.

\section{CREATING LIFE WITH THE INTENTION OF ENDING IT} TO PROVIDE TISSUE

Using cloning to produce embryos or fetuses as a source of tissue would involve deliberately creating life for the purposes of destroying it. It involves intentionally killing the fetus. This differs from abortion where women do not intend to become pregnant for the purpose of having an abortion.

Is it wrong deliberately to conceive a fetus for the sake of providing tissue? Most of the guidelines on the use of fetal tissue aim to stop women having children just to provide tissues. ${ }^{41}$ The reason behind this is some background belief that abortion is itself wrong. These guidelines aim to avoid moral taint objections that we cannot benefit from wrong-doing. More importantly, there is a concern that promoting some good outcome from abortion would encourage abortion. However, in this case, abortion would not be encouraged because this is abortion in a very special context: it is abortion of a cloned fetus for medical purposes.

But is it wrong deliberately to use abortion to bring about some good outcome?

In some countries (for example those in the former Eastern bloc), abortion is or was the main available form of birth control. A woman who had intercourse knowing that she might fall pregnant, in which case she would have an abortion, would not necessarily be acting wrongly in such a country, if the alternative was celibacy. When the only way to achieve some worthwhile end - sexual expression - is through abortion, it seems justifiable.

The question is: is the use of cloned fetal tissue the best way of increasing the pool of transplantable tissues and organs? ${ }^{\text {?2 }}$

\section{AN OBJECTION TO THE PRINCIPLE OF TISSUE \\ TRANSMUTATION}

Another objection to the proposal is that we do not have the right to determine the fate of all our cells. For example, we are limited in what we can do with our sex cells. However, we should only be constrained in using our own cells when that use puts others at risk. This is not so in transmutation until another individual with moral interests comes into existence.

\section{SURROGACY CONCERNS}

At least at present, later embryonic and fetal development can only occur inside a woman's uterus, so some of the proposals here would require a surrogate. I have assumed that any surrogate would be freely consenting. Concerns with surrogacy have been addressed elsewhere, ${ }^{43}$ though cloning for this purpose would raise some different concerns. There would be no surrogacy concerns if the donor cell were derived from the mother (she would be carrying one of her own cells), from the mother's child (she would be carrying her child again) or if an artificial womb were ever developed.

\section{SHOULD WE GIVE GREATER IMPORTANCE TO} SOMATIC CELLS?

I have claimed that the totipotent cells of the early embryo, and indeed the embryo, do not have greater moral significance than adult skin cells (or indeed lung or colon or any nucleated cells). I have used this observation to downgrade the importance we attach to embryonic cells. However, it might be argued that we should upgrade the importance which we attach to somatic cells.

This is a reductio ad absurdum of the position which gives importance to the embryo, and indeed which gives weight to anatomical structure rather than function. If we should show special respect to all cells, surgeons should be attempting to excise the very minimum tissue (down to the last cell) necessary during operations. We should be doing research into preventing the neuronal loss which occurs normally during childhood. The desquamation of a skin cell should be as monumental, according to those who believe that abortion is killing persons, as the loss of a whole person. These claims are, I think, all absurd.

\section{YUK FACTOR}

Many people would find it shocking for a fetus to be created and then destroyed as a source of organs. But many people found artificial insemination abhorrent, IVF shocking and the use of animal organs revolting. Watching an abortion is horrible. However, the fact that people find something repulsive does not settle whether it is wrong. The achievement in applied ethics, if there is one, of the last 50 years has been to get people to rise above their gut feelings and examine the reasons for a practice. 
PERMISSIVE AND OBSTRUCTIVE ETHICS

Many people believe that ethicists should be merely moral watch-dogs, barking when they see something going wrong. However, ethics may also be permissive. Thus ethics may require that we stop interfering, as was the case in the treatment of homosexuals. Ethics should not only be obstructive but constructive. To delay unnecessarily a good piece of research which will result in a life-saving drug is to be responsible for some people's deaths. It is to act wrongly. This debate about cloning illustrates a possible permissive and constructive role for ethics.

\section{Conclusion}

The most justified use of human cloning is arguably to produce stem cells for the treatment of disease. I have argued that it is not only reasonable to produce embryos as a source of multipotent stem cells, but that it is morally required to produce embryos and early fetuses as a source of tissue for transplantation. This argument hinges on:

1. The claim that the moral status of the cloned embryo and early fetus is no different from that of the somatic cell from which they are derived.

2. The claim that there is no morally relevant difference between the fetus and the embryo until some critical point in brain development and function.

3. The fact that the practice is consistent with existing practices of fetal tissue transplantation and conceiving humans as a source of tissue for transplantation (the Ayala case).

4. An argument from beneficence. This practice would achieve much good.

5. An argument from autonomy. This was the principle of tissue transmutation: that we should be able to determine the fate of our own cells, including whether they change into other cell types.

This proposal avoids all the usual objections to cloning. The major concerns are practicality and safety. This requires further study.

The HGAC and The Royal Society have broached the possibility of producing clones for up to 14 days: "therapeutic cloning". Those bodies believe that it is acceptable to produce and destroy an embryo but not a fetus. Women abort fetuses up to 20 weeks and later. We could make it mandatory that women have abortions earlier (with rapid pregnancy testing). However, we do not. Moreover, while the decision for most women to have an abortion is a momentous and considered one, in practice, we allow women to abort fetuses regardless of their reasons, indeed occasionally for no or bad reasons. If a woman could abort a fetusm because she wanted a child with a certain $\overline{\bar{\sigma}}$. horoscope sign, surely a woman should be able to? abort a fetus to save a person's life.

I have been discussing cloning for the purposes? of saving people's lives or drastically improving their quality. While we beat our breasts abouto human dignity and the rights of cells of different跑 sorts, people are dying of leukaemia and kidneyo disease. If a woman wants to carry a clone of her? or someone else's child to save a life, it may not be society's place to interfere.

The recent development of human totipotent stem cell lines from embryonic tissue ${ }^{445}$ means that we are closer to understanding cellular devel opment and differentiation, generating the hope that we may be able to produce tissue foroo transplantation directly from totipotent stem cells without going to the stage of producing a mature? embryo or fetus. But that is still some way off, and at present requires deriving the cell lines from embryonic tissue. The use of nuclear transfer may still be the best way to produce highly compatibles tissue, even coupled with this technology.

We could address the shortage of tissue foro transplantation now. We could routinely employs embryo-splitting during IVF and create embryo banks as a source of fetal tissue. Indeed, rathero than destroying millions of spare embryos, we could use them as a source of human tissue. Asô opposed to using nuclear transfer as a source of tissue, such proposals could not be instituted with the consent of a person who both needs the tissue and is the source of the tissue. That is, we could not appeal to the Principle of Tissue Transmutation to justify these proposals, though they may be justifiable on other grounds.

\section{Acknowledgement}

Many thanks to Jeff McMahan, Bob Williamson David McCarthy, Edgar Dahl, Peter Singer, Lynn Gillam and Ainsley Newson.

\section{Funding}

The Murdoch Institute and The Cooperative Research Centre for Discovery of Genes for Common Human Diseases.

Fulian Savulescu, $M B, B S, B M e d S c i, P h D$, is Director of the Ethics Unit, The Murdoch Institute, Royal Chil dren's Hospital, Melbourne, Australia and Associate⿻ Professor at the Centre for the Study of Health And $\overrightarrow{\mathbb{B}}$ Society, University of Melbourne.

\section{References and notes}

1 I use the word "embryo" to cover all stages of development from the single-cell stage to the stage at which there is signifie 
cant organogenesis (about the eighth week), after which I will refer to the growing human as a "fetus". I do not differentiate between a pre-embryo and an embryo.

2 National Bioethics Advisory Commission. Cloning human beings. Maryland: National Bioethics Advisory Commission, 1997.

3 World Health Organisation. Proposed international guidelines on ethical issues in medical genetics and genetics services. Geneva: WHO, 1998.

4 The European Parliament. Resolution on cloning. Motion dated March 11 1997. Passed March 13 1997. The European Parliament, 1997

5 UNESCO. Declaration on the human genome and human rights, adopted on 11 November 1997(13), article 11. UNESCO, 1997.

6 Butler D. Europe brings first ban. Nature 1998;391:219.

7 HGAC. HGAC Papers. Cloning issues in reproduction, science and medicine. Issued for comment January 1998 at http:// www.dti.gov.uk/hgac/papers/papers_c.htm.

8 Human Cloning Prohibition Act of 1998, 105th Congress, 2nd Session. S 1599

9 Human Cloning Prohibition Act of 1998, 105th Congress, 1st Session. HR 923.

10 Harris J. Goodbye Dolly? The ethics of human cloning. fournal of Medical Ethics 1997;23:353-60.

11 Singer P. forthcoming.

12 Childress JF. The challenges of public ethics: reflections on the NBAC's report. Hastings Center Report 1997; 27, 5.

13 Trounson A. Cloning: potential benefits for human medicine. Medical fournal of Australia 1997;167:568-9.

14 Kassirer JP, Rosenthal NA. Should human cloning research be off limits? New England fournal of Medicine 1998;338:905-6.

15 Council of the Royal Society. Whither cloning? London: The Royal Society: The UK Academy of Science, 1998: 1-8.

16 Every cell division results in genetic differences between progeny which are not completely repaired by DNA repair mechanism. Though the vast majority of these differences have no functional implications, they are differences none the less and cellular division does not normally produce an exactly identical copy of DNA (Pannos Iannou, personal communication).

17 Cohen P. Organs without donors. New Scientist 1998 Jul 11: 4.

18 Weiss MJ, Orkin SH. In vitro differentiation of murine embryonic stem cells: new approaches to old problems. fournal of Clinical Investigation 1996;97:591-5.

19 Platts JL. New directions for organ transplantation. Nature 1998;392:11-7.

20 Cooper DKC. Xenotransplantation-state of the art. Frontiers of Bioscience 1996;1:248-65.

21 Dorling A et al. Clinical xenotransplantation of solid organs. Lancet 1997;349:867-71.

22 It is not clear whether different patterns of $\mathrm{X}$ inactivation or the different mitochondrial complement of cloned cells will affect immunocompatibility.

23 Prior to this point, cells have the potential to develop into several tissue types and there is a lack of coordinated functiona activity. For example, Michael Lockwood has argued that early on it is not determined which cells will become the fetus and which the placenta (Lockwood M. Human identity and the primitive streak. Hastings Center Report 1995;Jan-Feb:45). It is not clear until much later which cells will become the brain and which the liver. Indeed, early on, the primitive embryo has the capacity to divide into identical twins. Lockwood's argument is that it is only when the definite precursor of a person's brain is formed that a discrete and determined individual can be said to exist.
24 Even an embryo formed by conception in the usual way may not become a person-a significant proportion are spontaneously aborted.

25 Vawter DE, Kearney W, Gervaise KG, Caplan AL, Garry D, Tauer C. The use of human fetal tissue: scientific, ethical and policy concerns. Minnesota:University of Minnesota, 1990: 38-41.

26 Keleman E. Recovery from chronic idiopathic bone marrow aplasia of a young mother after intravenous injection of unprocessed cells from the liver (and yolk sac) of her $22 \mathrm{~mm}$ CR-length embryo. A preliminary report. Scandinavian fournal of Haematology 1973;10:305-8.

27 Lindvall O. Neural transplantation. Cell Transplantation 1995;4, 4:393-400.

28 Freeman TB. From transplants to gene therapy for Parkinson's disease. Experimental Neurology 1997;144,1:47-50.

29 Shannon KM, Kordower JH. Neural transplantation for Huntington disease: experimental rationale and recommendations for clinical trials. Cell Transplantation 1996;5,2:339-52.

30 Freeman TB, Sanberg PR, Isacson O. Development of the human striatum: implications for fetal striatal transplantation in the treatment of Huntington disease. Cell Transplantation 1995;4,6:539-45.

31 Zompa EA, Cain LD, Everhart AW et al. Transplant therapy: recovery of function after spinal cord injury. Fournal of Neurotrauma 1997;14,8:479-506.

32 del Cerro M, Lazar ES, Diloreto D Jr. The first decade of continuous progress in retinal transplantation. Microscopy Research and Technique 1997;36,20:130-41.

33 Litchfield TM, Whitely SJ, Lund RD. Transplantation of retinal pigment epithelial, photoreceptor and other cells as treatment for retinal degeneration. Experimental Eye Research $1997 ; 64,5: 655-66$

34 Shetty AK, Turner DA. Development of fetal hippocampal grafts in intact and lesioned hippocampus. Progress in Neurobiology 1996; 50,5-6:597-653.

35 Touraine JL. In utero transplantation of fetal liver stem cells into human fetuses fournal of Hematotherapy 1996; 5,2:195-9.

36 Rachels J. When philosophers shoot from the hip. Bioethics 1991;5:66-71.

37 Note in Hastings Center Report 1994; May/June: 2.

38 Lamperd R. Race for Life. Sun Herald 1998 Jul 2:1

39 Burthchaell JT. University policy on experimental use of aborted fetal tissue. IRB: A Review of Human Subjects Research 1988;10:7-11.

40 Holm S. A life in the shadow: one reason why we should not clone humans. Cambridge Health Care Quarterly 1998;7:160-2.

41 See reference 25: the whole book.

42 Some argue that opt-out systems of organ procurement, umbilical cord blood and xenotransplantation offer viable alternatives. I would take an organ derived from one of my own cells, if concerns about aging and increased mutation were adequately addressed.

43 Oakley J. Altruistic surrogacy and informed consent. Bioethics 1992;6,4:269-87.

44 Thomson JA, Itskovitz-Eldor J, Shapiro SS, Waknitz MA, Swiergiel J et al. Embryonic stem cell lines derived from human blastocysts. Science 1998;282:1145-7.

45 Shamblott MJ, Axelman J, Wang S, Bugg EM, Littlefield JW et al. Derivation of pluripotent stem cells from cultured human primordial germ cells. Proceedings of the National Academy of Sciences 1998;95:13,726-31. 